\title{
UPAYA PENINGKATAN PENGETAHUAN MASYRAKAT DESA PRAGAAN LAOK KABUPATEN SUMENEP DALAM MENGHADAPI PANDEMIC COVID 19
}

\author{
Purwanto $^{1}$, Isnain Bustaram ${ }^{2}$, Ach. Resa fachrizi ${ }^{3}$ \\ 1,2,3 Universitas Madura \\ E-mail : purwanto@unira.ac.id
}

\section{Submitted : 19 Agustus 2021 Accepted: 26 Agustus 2021 Published: 31 Agustus 2021}

\begin{abstract}
Abstrak: Virus Corona ditularkan dari hewan ke manusia, dan penularan dari manusia ke manusia sifatnya terbatas. Infeksi virus corona dapat menyebabkan pneumonia hingga kematian. Munculnya wabah penyakit Corona Virus Diseases-19 mendorong pentingnya untuk memberikan edukasi dan penyadar tentang pentingnya pola hidup bersih dan sehat serta menjelaskan pola penularan virus covid 19 kemudian mengedukasi kasih masyarakat bagaimana pentingnya memakai masker dan menjaga jarak untuk pencegahan covid 19. Tujuan dari kegiatan ini adalah untuk meningkatkan kewaspadaan dan pengetahuan para masyarakat di desa pragaan laok melalui kegiatan penyuluhan serta pendampingan mengantisipasi merebaknya pandemi Covid-19. Metode pelaksanaan kegiatan ini diawali dengan kegiatan koordinasi dan komunikasi dengan pihak desa pragaan laok. Persiapan dimaksudkan adalah penetapan arah dan sasaran kegiatan, kemudian penyampaian pengetahuan menggunakan slide mengenai infeksi corona virus dan diakhiri dengan sesi tanya jawab. Dari kegiatan ini diharapkan terdapat peningkatan pengetahuan para masyarakat tentang pencegahan terjadinya infeksi corona virus yang menjadi epidemi global saat ini sehingga meningkatkan kewaspadaan terhadap bahaya penyebaran infeksi virus corona ini.
\end{abstract}

Kata Kunci: Covid-19, Pencegahan, Penyuluhan Kesehatan 


\section{PENDAHULUAN}

Secara administrasi Desa Pragaan Laok berada di tengah-tengah Kecamatan Pragaan dan di ujung barat Kabupaten Sumenep kurang lebih $30 \mathrm{~km}$ dari Kota Sumenep dan berbatasan dengan desa-desa lain yang ada di Kecamatan Pragaan, sebelah utara berbatasan dengan Desa Pragaaan Daya, sebelah barat dengan Desa Jaddun, dan sebelah timur dengan Desa Prenduan. Pragaan Laok adalah sebuah nama desa yang berada di Kecamatan Pragaan, Kabupaten Sumenep, Provinsi Jawa Timur. Desa Pragaan Laok memiliki 6 dusun/ kampung yang terdiri dari Maronggi Laok, Maronggi Daya, Mornangka, Dung Laok, Dung Daya, Aeng Soka. Di desa ini terdapat kurang lebih 5.507 jiwa yang mayoritas berprofesi sebagai petani.

Disaat pandemiCovid-19, Mayoritas petani di Desa Pragaan Laok tetap melaksanakan tanam padi tanam jagung yang berlangsung sampai bulan April lalu, dan saat ini sudah ada sebagian yang sudah panen. Kebutuhan hidup ialah alasan masyarakat setempat tetap bekerja di kebun/sawah dan yang menjadi perhatian adalah kebanyakan masyarakat yang bekerja di luar rumah tanpa menggunakan masker. Kondisi ini sangat penting untuk mendapatkan perhatian karena sangat rentan dengan penyebaran wabah Covid-19 yang akhir-akhir ini menimbulkan keresahan seluruh lapisan masyarakat. Namun, berkembanganya isuisu yang kurang bertanggung jawab dapat menjadi permasalahan penting dalam program pengendalian wabah Covid-19 di Desa Pragaan Laok pada khususnya. Minimnya pengetahuan dan pemahaman penduduk mengenai informasi yang valid tentang virus Covid-19 dapat menimbulkan dampak sosial yang besar. Upaya pencegaham yang dapat dilakukan adalah dengan melakukan berbagai kegiatan, salah satunya adalah kegiatan penyuluhan untuk dapat memberikan data dan informasi yang ilmiah kepada seluruh lapisan masyarakat mengenai wabah virus Covid-19 di Kabupaten Sumenep dan Desa Pragaan Laok Pada Khususnya. Pengetahuan dan pemahaman yang ilmiah, akurat dan dapat dipercaya akan dapat membantu masyarakat untuk mudah melaksanakan himbuan dan arahan pemerintah guna menekan penyebaran Covid-19 di Desa Pragaan Laok. Atas dasar inilah, telah dilakukan kegiatan penyuluhan kesehatan untuk meningkatkan pengetahuan penduduk Desa Pragaan Laok agar dapat menghadapi dan melewati pandemi Covid-19.

\section{TINJAUAN PUSTAKA}

\subsection{Pengertian Covid-19}

Covid-19 adalah penyakit menular yang diakibatkan infeksi virus Covid-19 yang merupakan virus jenis baru. Penyakit ini diketahui muncul pertama kali di Wuhan, Cina pada Desember 2019 (WHO, 2020). Covid-19 merupakan penyakit pernapasan akut yang menjadi pandemi global dan disebabkan oleh virus SAR-Cov-2 (Erlich, 2020).

\subsection{Tanda dan Gejala Penderita Covid-19}

Gejala Covid-19 antara lain demam, batuk kering, dan sesak napas. Beberapa pasien mengalami gejala mirip pilek dan mengalami nyeri pada tenggorokan dan diare. Beberapa orang yang terinfeksi tidak menunjukkan gejala dan merasa sehat. Sebagian dapat pulih dengan sendirinya, sedangkan sebagian lainnya mengalami perburukan kondisi sehingga mengalami kesulitan bernapas dan perlu dirawat di rumah sakit (WHO, 2020).

\subsection{Cara Penularan Covid-19}

Covid-19 dapat menular dari orang yang terinfeksi kepada orang lain di sekitarnya melalui percikan batuk atau bersin. Covid-19 juga dapat menular melalui 
benda-benda yang terkontaminasi percikan batuk atau bersin penderita Covid-19. Orang lain yang menyentuh benda-benda terkontaminasi tersebut lalu menyentuh mata, hidung dan mulut mereka dapat tertular penyakit ini (WHO, 2020) .Virus penyebab Covid-19 dapat bertahan di udara sekitar satu jam, sedangkan di permukaan benda-benda dapat bertahan selama beberapa jam. Di permukaan berbahan plastic dan besi tahan karat virus dapat bertahan hingga 72 jam, pada cardboard selama 24 jam dan pada tembaga bertahan selama 4 jam (Doremalen, et al., 2020).

\subsection{Cara Pencegahan Covid-19}

Beberapa langkah pencegahan Covid-19 yang direkomendasikan oleh WHO pada tahun 2020 antara lain:

1. Sering mencuci tangan menggunakan sabun dan air mengalir atau antiseptic berbahan alkohol. Deterjen pada sabun dan alkohol pada antiseptik dapat membunuh virus pada tangan.

2. Jaga jarak dengan orang lain minimal satu meter. Hal ini untuk mencegah tertular virus penyebab Covid-19 dari percikan bersin atau batuk.

3. Hindari menyentuh mata, hidung dan mulut sebelum Anda memastikan tangan Anda bersih dengan mencuci tangan menggunakan sabun dan air mengalir atau antiseptik. Tangan yang terkontaminasi dapat membawa virus ini ke mata, hidung dan mulut yang menjadi jalan masuk virus ini ke dalam tubuh dan menyebabkan penyakit Covid-19.

4. Tetaplah berada di dalam rumah agar tidak tertular oleh orang lain di luar tempat tinggal.

\section{METODE PELAKSANAAN}

\subsection{Observasi}

Observasi atau yang disebut pula dengan pengamatan meliputi kegiatan pemuatan perhatian terhadap lingkungan sekitar dengan menggunakan seluruh alat indra. Jadi, teknik pengumpulan data yang ini melakukannya dengan teknik pemantauan atau melihat langsung terhadap objek penelitian dan melakukan pencatatan hasil pengamatan dari kegiatan-kegiatan di Desa Pragaan Laok.

\subsection{Sosialisasi}

Melaksanakan sosialisasi kepada masyarakat tentang bahaya Covid-19 dengan mendatangi kediaman ataupun dibalai desa tempat dimana masyarakat berkumpul.

\subsection{Informasi melalui Media Sosial.}

Memberi informasi akurat serta cara mencegah ataupun memutus mata rantai Covid-19 ini di desa Pragaan Laok melalui media sosial seperti media cetak dan semacamnya.

\subsection{Pemeriksaan atau Check Point}

Membantu relawan setempat melakukan pemeriksaan kesehatan masyarakat dari luar daerah atau pendatang. Jika menemukan pendatang yang mengeluhkan gejala, maka secara otomatis relawan akan mencatat sebagai Orang Dalam Pemantauan (ODP).

\subsection{Membantu kegiatan relawan}

Membantu kegiatan relawan setempat di posko covid desa seperti menyiapkan tempat cuci tangan, dan sebagainnya. 


\section{HASIL DAN PEMBAHASAN}

Program Kegiatan pengabdian masyarakat ini diwujudkan melalui sosialisasi waspada infeksi virus Covid-19 di Desa Pragaan Laok yang berjalan sesuai yang rencanakan, beberapa kegiatan yang diprogramkan bisa terlaksana dengan baik seperti:

a. Sosialisasi pada masyarakat tentang bahaya Covid dan cara pencegahannya dengan peserta sebanyak 25 orang . Dengan mengundang masyarakat kebalai desa guna penyamian edukasi bersama satgas posko covid desa untuk menerapkan hidup sehat dan memberi panduan untuk mencegah covid 19.

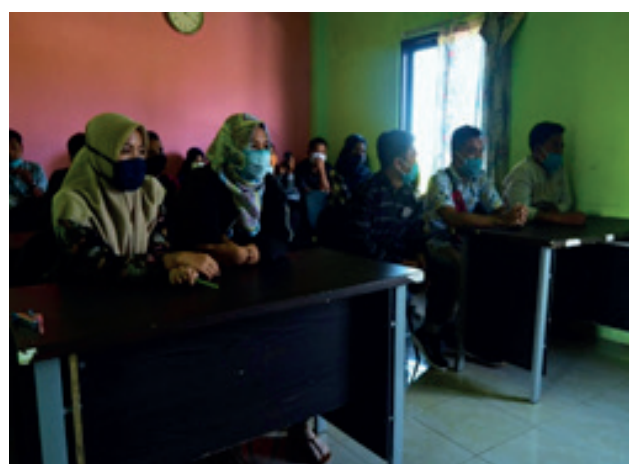

Gambar 1. Sosialisasi bahaya covid 19

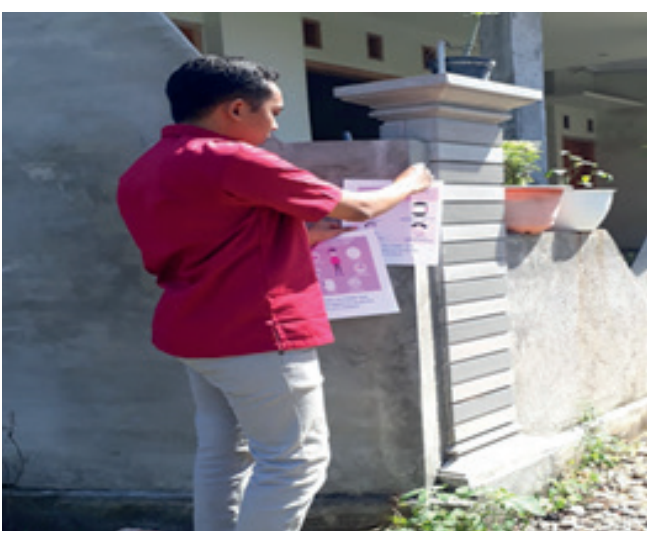

Gambar.2 pemasangan pamflet

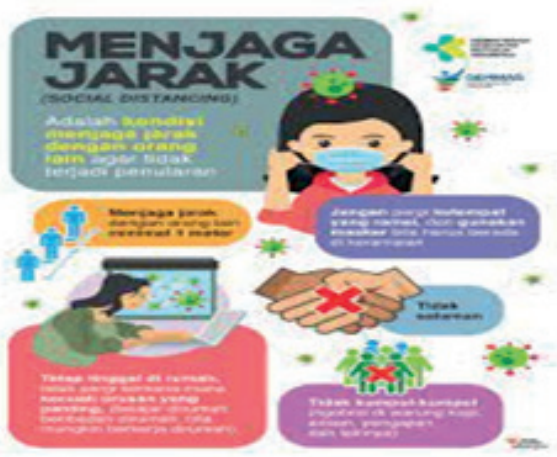

Gambar.3 Design pamflet

b. Memberikan informasi melalui media cetak seperti banner dan pamlet Covid 19. Memasang pamflet dan Banner tentang covid 19 di tempat umum sebagai informasi kepada masyarakat.

c. Pembagian masker dan pemberian handsanitizer ke tempat kerja masyarakat. Mendatangi tempat kerja masyarakat untuk membagikan masker pada masyarakat yang bekerja di luar rumah tanpa menggunakan masker dan memberikan handsanitizer, karena mayoritas masyarakat pragaan laok bekrja di luar rumah sebagai petani.

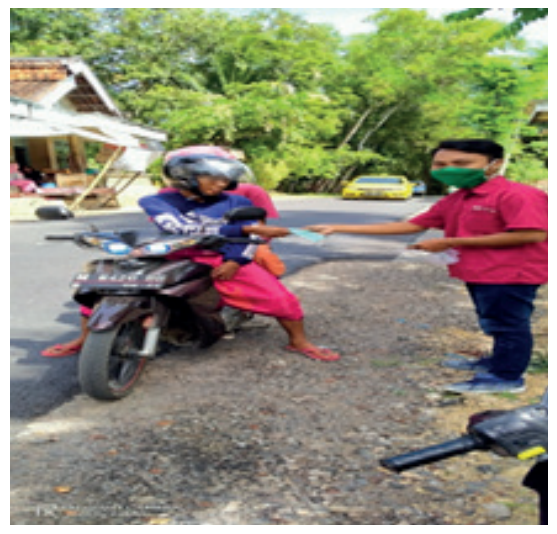

Gambar.4 pembagian masker

d. Membantu setiap kegiatan yang dilaksanakan oleh relawan setempat. Turut serta dalam kegiatan yang dilaksanakan relawan desa setempat seperti menyiapkan fasilitas di posko, membersihkan tempat 
ibadah dan membantu melaksanakan check point di jalan utama Pamekasan Sumenep.

Dampak dari kegiatan Kuliah Kerja Nyata di masa pandemi Covid 19 ialah :

1. Sosialisasi, masyarakat tidak perlu keluar rumah untuk mendapatkan informasi tentang pelayanan kesehatan, tentang bahaya dan cara mencegah covid-19 karena relawan posko yang mendatangi kediaman masyarakat sehingga berdampak pada kesehatan masyarakat untuk mencegah penyebaran virus Covid-19 dengan tidak banyak melakukan aktifitas di luar rumah dan termasuk anjuran pemerintah untuk di rumah saja.

2. Kegiatan pembagian masker dan handsanitizer sebagai upaya untuk menganjurkan penggunaan masker dan handsanitizer karena sangat penting untuk kesehatan di saat pandemi seperti sekarang ini sehingga dampak perubahan dari kegiatan tersebut ialah masyarakat yang semakin disiplin dalam penggunaan masker saat melakukan aktifitas di luar rumah sehingga dapat menekan penyebaran Covid-19.

3. Adanya kegiatan pemasangan pamflet dan banner berdampak pada masyarakat agar menjadi ingat setiap melewati daerahdaerah yang sudah dipasangkan banner dan masyarakat paham mengenai gejala dan pencegahan seperti selalu menggunakan masker setiap keluar rumah, tidak banyak beraktifitas diluar rumah, kecuali ada hal yang sangat penting, sehingga dapat memutus rantai Covid-19.

4. Kegiatan check point bersama relawan dan satgas Covid-19. Setiap masyarakat yang tidak memakai masker saat berkendara, petugas sigap memberhentikan dan meminta masyarakat untuk memakai masker. Begitupun, jika ada kendaraan dari luar daerah khususnya dari luar kota, petugas memerintahkan untuk putar balik. Dampak dari ketegasan dan ketertiban ini ialah tidak ada lagi pendatang yang dikhawatirkan terpapar oleh virus dan tinggal di daerah Kecamatan Pragaan yang bisa menyebabkan masyarakat Pragaan Laok dan sekitarnya terjangkit Covid-19.

5. Kegiatan pembersihan tempat ibadah berdampak pada masyarakat Desa Pragaan Laok yang tidak lagi hawatir untuk melaksakan ibadah di masjid-masjid karena sudah terjamin ke bersihannya.

\section{KESIMPULAN}

Kesimpulan yang diperoleh dari hasil kegiatan pengabdian masyarakat ini adalah warga Pragaan Laok telah mendapatkan pencerahan dan penjelasan mengenai virus Covid-19-19 yang sedang mewabah di berbagai negara bahkan telah sampai di Madura. Warga Pragaan Laok juga telah mendapatkan pengetahuan mengenai pola hidup bersih dan sehat dengan baik. Adanya program ini kami dapat memberikan edukasi/ sosialisasi tentang bahaya wabah virus Covid-19 kepada seluruh masyarakat Pragaan Laok dan dapat mengetahui bagaimana caranya untuk menangani dan tidak tertular wabah virus Covid-19 ini.

\section{UCAPAN TERIMAKASIH}

Tim Pelaksana Pengabdian ini mengucapkan terima kasihkepada Kepala Desa Pragaan Laok, Kepala Lembaga Penelitian dan Pengabdian Masyarakat Universitas Madura atas dukungan dan bantuan sehingga kegiatan ini dapat terselenggara dengan sebaik-baiknya. 


\section{DAFTAR PUSTKA}

Doremalen van, N, et al. (2020). Aerosol and Surface Stability of SARS-CoV-2 as Compared with SARS-CoV-1. In The New England journal of medicine (Vol. 382, Issue 16, pp. 1564-1567). NLM (Medline). https://doi.org/10.1056/NEJMc2004973

Erlich. 2020. COVID-19 (Novel Coronavirus). (n.d.). Retrieved May 11, 2020, from https://www.dynamed.com/ condition/covid-19-novel-coronavirus/

Kemkes.2020. Gugus Tugas Percepatan Penanganan COVID-19. (n.d.). Retrieved April 28,2020, from https://www.covid19. go.id/

Pentingnya Menerapkan Social Distancing Demi Mencegah COVID-19 - Alodokter. (n.d.). Retrieved April 28, 2020, from https://www.alodokter.com/pentingnyamenerapkansocial-distancing-demimencegah-covid-19

WHO.2020.Pertanyaan jawaban terkait COVID-19 untuk publik. (n.d.). Retrieved April 28, 2020, from https://www.who.int/ indonesia/news/novel-coronavirus/qa-forpublic 